\author{
Beata Szymańska
}

\title{
Satysfakcja komercyjnego klienta usług sanatoryjnych w Polsce
}

\section{Wstęp}

Zdrowie od najdawniejszych czasów stanowiło przedmiot zainteresowania człowieka. Zainteresowanie to wzrastało w obliczu zagrażającej lub zaistniałej choroby. Współcześnie zdrowie jest traktowane jako wartość, zasób, dzięki któremu możemy urzeczywistniać swoje aspiracje i plany, zaspokajać potrzeby, radzić sobie z wyzwaniami współczesnego świata. Inwestowanie we własne zdrowie, odpowiedzialność za nie, stało się normą w nowoczesnych społeczeństwach, a profilaktyka zdrowotna uznawana jest za priorytetową w ochronie zdrowia.

Rynek zdrowotny, dla którego zdrowie stało się produktem, intensywnie się rozwija, poszerzając i doskonaląc swoją ofertę. Obejmuje on m.in. rynek urody i sprawności fizycznej, zdrowej żywności, chirurgii plastycznej, suplementów diety, turystyki zdrowotnej. Obserwuje się rosnący wzrost wydatków na prewencję i opiekę zdrowotną w gospodarstwach domowych ${ }^{1}$ osób, które chcą być zdrowe i o zdrowie swoje tudzież swoich bliskich się troszczą.

Jednym ze sposobów zapobiegania chorobom, służącym także regeneracji sił fizycznych, psychicznych, a także duchowych jest czasowa zmiana miejsca pobytu i stylu życia, taką możliwość daje wyjazd do uzdrowiska.

Styl życia uznawany jest przez Światową Organizację Zdrowia za jeden z podstawowych wśród czynników determinujących osobnicze zdrowie człowieka. Styl życia jest sposobem życia, który opiera się na wzajemnym oddziaływaniu warunków życia i indywidualnych wzorców zachowania określonych przez czynniki społeczno-kulturowe i osobiste cechy charakteru. Związki pomiędzy stylem życia a zdrowiem są od dawna znane i wykorzystywane w podejmowaniu działań mających służyć poprawie zdrowia. Takimi działaniami są m.in. pobyty w uzdrowiskach mające przywrócić sprawność i siły nadwerężone poprzez niekorzystne

${ }^{1}$ Szerzej na ten temat w: GUS, Departament Badań Społecznych i Warunków Życia, Narodowy Rachunek Zdrowia za 2011 r. Materiał na konferencję prasową w dniu 23.07.2013 r. 
warunki życia współczesnego człowieka, wynikające z rozwoju cywilizacyjnego. Należy podkreślić, że warunki te będą spełnione wówczas, jeżeli kuracjusz spotka się z ofertą spełniającą jego wymagania i oczekiwania, a pobyt w uzdrowisku w pełni go usatysfakcjonuje.

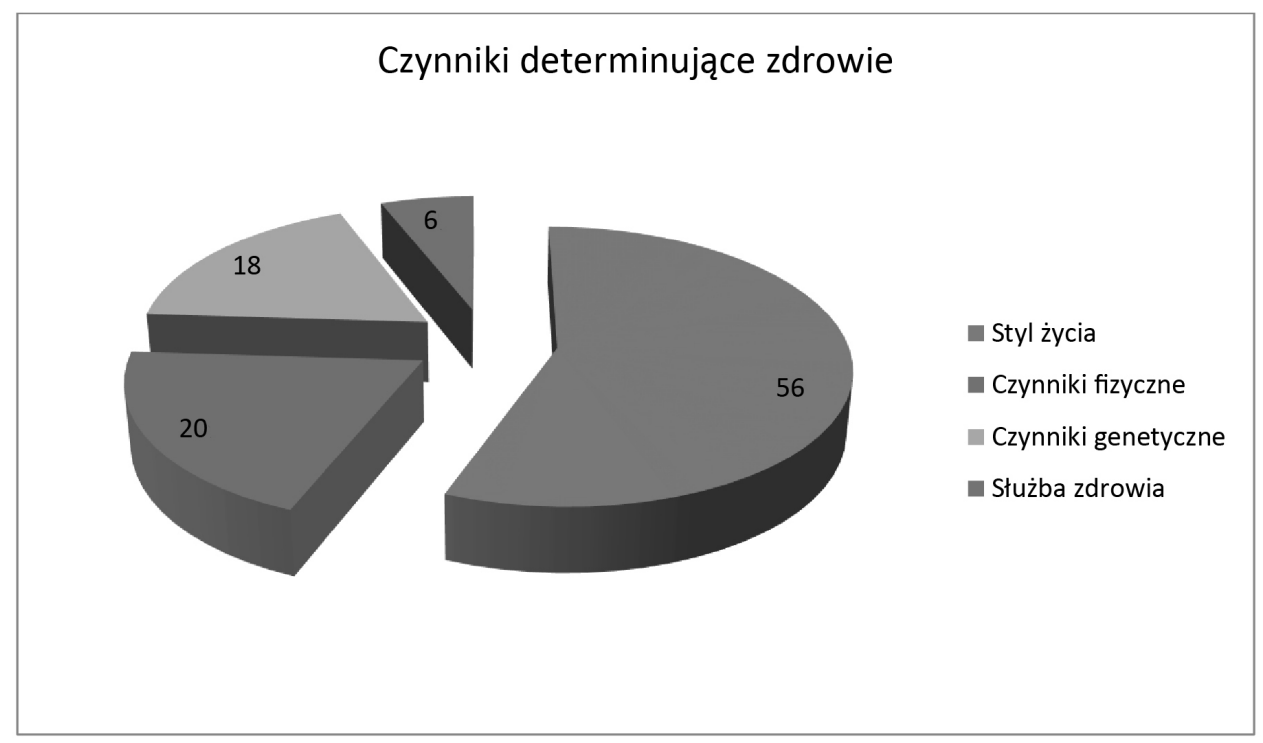

Rysunek 1. Osobnicze uwarunkowania zdrowia (w \%)

Źródło: M. Lalonde, A New Perspective on the Canadians, Working Document, Minister of National Health and Welfare, Ontario 1974.

Celem niniejszego artykułu jest poszukiwanie odpowiedzi na pytania: jakie czynniki determinują satysfakcję komercyjnych kuracjuszy polskich uzdrowisk oraz jaki jest jej poziom. Pogłębienie wiedzy w tym zakresie może usprawnić zarządzanie usługami zdrowotnymi świadczonymi przez sanatoria, a także wskazać kierunki zmian, które pozwolą nawiązać długotrwałe relacje z kuracjuszami, utrzymać stałych, lojalnych klientów i pozyskać nowych. W praktyce, lepsza znajomość tego zagadnienia może pozwolić poszczególnym sanatoriom czy też uzdrowiskom, skutecznie i efektywnie działać na specyficznym, konkurencyjnym rynku usług uzdrowiskowych. 


\section{Potencjał usługowy polskich uzdrowisk}

Usługa uzdrowiskowa jest unikatowa, świadczona jest bowiem przy wykorzystaniu zasobów specyficznych ${ }^{2}$, którymi są naturalne surowce lecznicze, mikroklimat, wyjątkowa lokalizacja. Rzadkość i ograniczenia przestrzenne w występowaniu tych zasobów powodują, iż są one niemożliwe do imitacji i substytuowania, a tym samym do wykorzystania przez konkurentów. Zdolność przedsiębiorstwa uzdrowiskowego do świadczenia usługi uzdrowiskowej to „powtarzające się wzorce działania w korzystaniu z zasobów w celu kreowania, produkowania i/lub oferowania produktów na rynku"3. Świadczenie wyjątkowych usług, jakimi są usługi uzdrowiskowe, warunkowane jest występowaniem zasobów specyficznych dla tego rynku.

Czynniki określające zdolność do świadczenia usług uzdrowiskowych możemy podzielić na dwie podstawowe grupy: są to obowiązujące uregulowania prawne oraz posiadany potencjał usługowy. Ustawa z dnia 28 lipca 2005 roku o lecznictwie uzdrowiskowym, uzdrowiskach i obszarach ochrony uzdrowiskowej oraz o gminach uzdrowiskowych ${ }^{4}$ definiuje podstawowe pojęcia oraz określa warunki niezbędne do świadczenia tych usług. Rozdział 2 art. 4.1 ustawy zawiera zapis mówiący o tym, że lecznictwo uzdrowiskowe jest integralną częścią systemu ochrony zdrowia ${ }^{5}$.

Można zatem usługi świadczone w uzdrowiskach i sanatoriach zaliczyć do grupy specyficznych świadczeń medycznych. Są one udzielane na zasadach określonych przez ustawę w rozdziale 2 art. 14 stwierdzających, że świadczenia zdrowotne w zakładach lecznictwa uzdrowiskowego są udzielane na podstawie wystawionego przez lekarza:

- skierowania na leczenie uzdrowiskowe albo,

- zaświadczenia o braku przeciwwskazań do korzystania z danego rodzaju świadczeń zdrowotnych $\mathrm{w}$ danym uzdrowisku' ${ }^{6}$.

Zapis ten oznacza, że pacjent/kuracjusz może korzystać z usług uzdrowiskowych refundowanych przez Narodowy Fundusz Zdrowia wówczas, gdy jest skierowany na leczenie przez lekarza, bądź na zasadach pełnej odpłatności, o ile nie ma przeciwwskazań lekarskich do korzystania z takiej formy leczenia czy rehabilitacji.

Przedsiębiorstwa uzdrowiskowe są heterogeniczne, posiadają unikatowe wiązki zasobów zarówno wewnętrznych, jak i zewnętrznych kształtujących ich potencjał usługowy, a także wpływających na kształt oferty uzdrowiskowej.

${ }^{2}$ M. Szymura-Tyc, Marketing we wspótczesnych procesach tworzenia wartości dla klienta i przedsiębiorstwa, Wyd. Akademii Ekonomicznej w Katowicach, Katowice 2006, s. 191.

3 Ibidem s. 195.

${ }^{4}$ DzU, 2005, nr 167, poz. 1399.

5 Ibidem, rozdz. 2, art. 4.1.1.

${ }^{6}$ Ibidem, rozdz. 2, art. 14. 
Transformacja ustrojowa przełomu lat 1989/1990 spowodowała zmiany na rynku ochrony zdrowia, w tym również na rynku usług uzdrowiskowych. Lecznictwo uzdrowiskowe jest integralną częścią systemu ochrony zdrowia. Funkcjonuje na podstawie ustawy z dnia 30 sierpnia 1991 roku o zakładach opieki zdrowotnej ${ }^{7}$, która wprowadziła do systemu ochrony zdrowia elementy wolnego rynku, co dało możliwość przekształcania placówek ochrony zdrowia, w tym również uzdrowisk, w niepubliczne zakłady opieki zdrowotnej. Mogą one konkurować na rynku usług medycznych, a także samodzielnie dysponować środkami finansowymi. Wraz ze zmianami ustrojowymi i gospodarczymi zmienił się sposób postrzegania własnego zdrowia przez Polaków, którzy zaczęli traktować je jako cenną wartość, stanowiącą zasób pozwalający na pełnienie określonych funkcji w społeczeństwie i realizację swoich planów i zamierzeń. Z biernych uczestników procesu leczniczo-rehabilitacyjnego stali się aktywnymi, współpracującymi usługobiorcami. Efektem tych zmian stało się zwiększone zapotrzebowanie na świadczenia uzdrowiskowe. Sanatoria, dostosowując się do warunków rynkowych, odpowiedziały na wzrastający popyt podażą usług uzdrowiskowych o coraz wyższym standardzie, ale od 1990 do 1995 roku zmniejszającą się ich liczbą. Po roku 1995 obserwuje się ponowny rozwój tego segmentu ochrony zdrowia, przejawiający się przede wszystkim w systematycznie wzrastającej liczbie łóżek, liczbie osób korzystających z kuracji, modernizacji istniejących obiektów, wprowadzaniu innowacyjnych produktów, oferowaniu dodatkowych korzyści klientom oraz dużej różnorodności propozycji dla kuracjuszy.

Tabela 1. Placówki lecznictwa uzdrowiskowego w latach 2004-2011

\begin{tabular}{|c|c|c|c|c|}
\hline Rok & $\begin{array}{c}\text { Szpitale } \\
\text { uzdrowiskowe }\end{array}$ & $\begin{array}{c}\text { Sanatoria } \\
\text { uzdrowiskowe }\end{array}$ & $\begin{array}{c}\text { Zakłady } \\
\text { przyrodolecznicze }\end{array}$ & $\begin{array}{c}\text { Przychodnie } \\
\text { uzdrowiskowe }\end{array}$ \\
\hline 2004 & 69 & 155 & - & 25 \\
\hline 2005 & 65 & 156 & - & 26 \\
\hline 2006 & 68 & 161 & - & 28 \\
\hline 2007 & 69 & 159 & - & 28 \\
\hline 2008 & 66 & 154 & - & 23 \\
\hline 2009 & 67 & 166 & - & 22 \\
\hline 2010 & 65 & 171 & - & 20 \\
\hline 2011 & 63 & 182 & 12 & 20 \\
\hline
\end{tabular}

Źródło: własne na podstawie Podstawowe dane z zakresu ochrony zdrowia roku 2005, 2006, 2007, 2008, 2011, GUS, Warszawa.

${ }^{7}$ DzU, 1191, nr 91, poz. 48, z późn. zm. 
W konsekwencji wprowadzonych w 2005 roku uregulowań prawnych (ustawa o lecznictwie uzdrowiskowym i obszarach ochrony uzdrowiskowej oraz o gminach uzdrowiskowych) zmieniła się metodologia gromadzenia danych oraz sposób ich prezentacji przez GUS. Stąd też w tab. 1 brak jest informacji o sanatoriach rehabilitacyjnych i liczbie pacjentów w nich przebywających. Sanatoria rehabilitacyjne w klasyfikacji GUS są prezentowane jako oddzielne jednostki, niefunkcjonujące w ramach zakładów lecznictwa uzdrowiskowego.

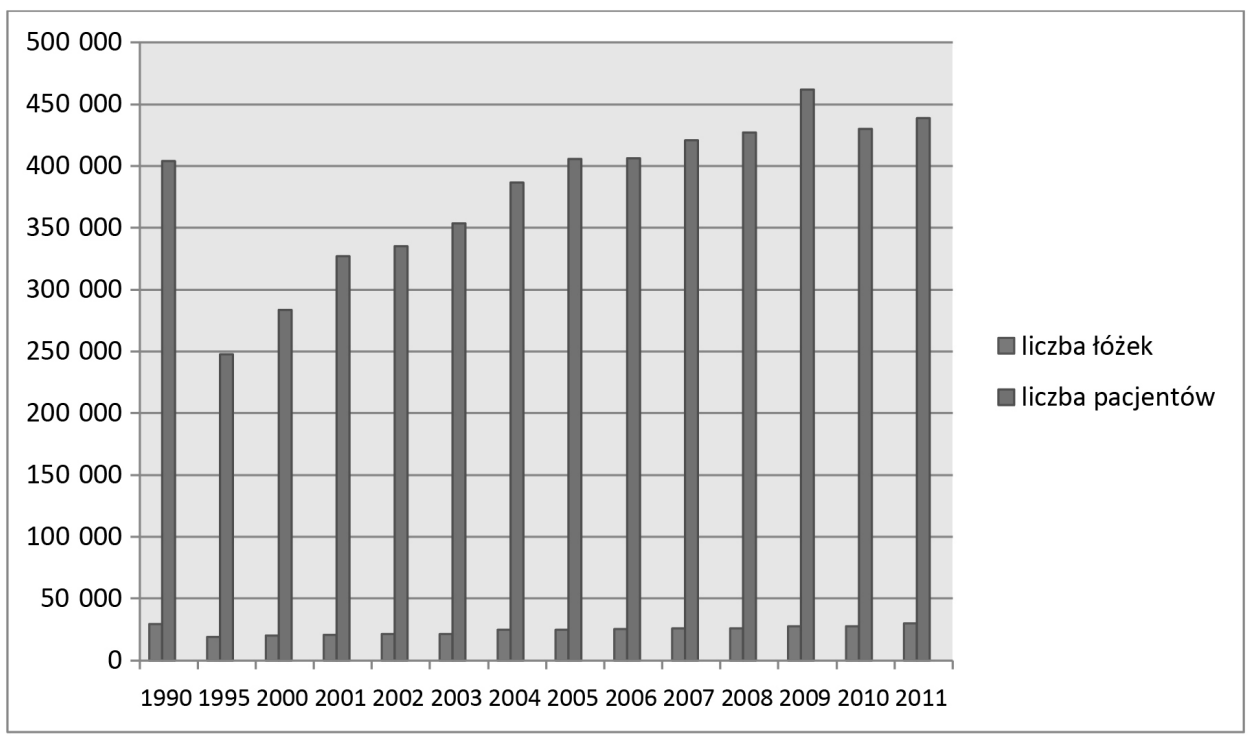

Rysunek 2. Liczba łóżek w sanatoriach uzdrowiskowych i stopień ich wykorzystania w latach 1990-2011

Źródło: opracowanie własne na podstawie Podstawowe dane z zakresu ochrony zdrowia 2005-20011 roku, GUS, Warszawa; Roczniki statystyczne województw 1991-2008.

W roku 1990 sanatoria uzdrowiskowe dysponowały prawie 30 tysiącami miejsc dla kuracjuszy. Do roku 2000 ich liczba systematycznie się zmniejszała, w krytycznym momencie spadła do 19943 łóżek. Od 2001 r. baza noclegowa ponownie była rozbudowywana, by osiągnąć w roku 2011 poziom z roku 1990. Również od roku 2001 obserwuje się systematycznie zwiększającą się liczbę kuracjuszy - od 326778 do $438615 \mathrm{w}$ roku 2011.

Liczba łóżek w szpitalach uzdrowiskowych pomiędzy rokiem 1990 a 2011 ulegała wahaniom. W roku 2008 osiągnęła poziom zbliżony do roku 2002 z liczbą 10239 miejsc w szpitalach uzdrowiskowych. W roku 2011 liczba ta zmniejszyła się i wynosiła 9658. Od roku 1990 do 2010 obserwowano zwiększającą się 
liczbę kuracjuszy. O ile w roku 2010 z terapii w polskich szpitalach uzdrowiskowych skorzystało 155728 pacjentów to w roku 2011 liczba ta zmniejszyła się do 137000 .

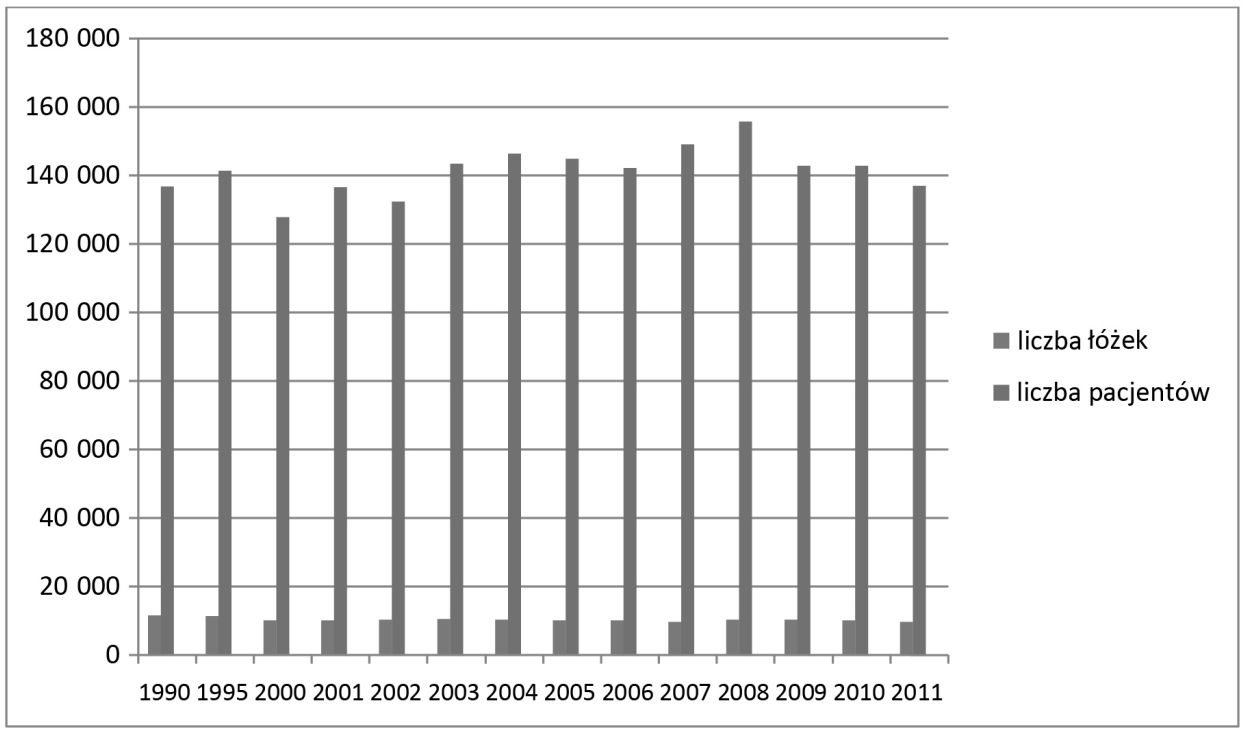

Rysunek 3. Liczba łóżek w szpitalach uzdrowiskowych i stopień ich wykorzystywania w latach 1990-2011

Źródło: jak do rys. 2.

Podsumowując należy podkreślić, że od roku 1995 wzrasta systematycznie liczba łóżek pozostających w dyspozycji sanatoriów uzdrowiskowych, przy jednoczesnym zmniejszaniu się liczby łóżek w szpitalach uzdrowiskowych. Z leczenia stacjonarnego w roku 2008 skorzystało 583000 osób, o 41\% więcej niż w roku 2000. Natomiast w 2011 roku było to 575 000. Analizując przytoczone dane można przypuszczać, że w warunkach rynkowych uzdrowiska lepiej zarządzają istniejącą bazą noclegową i efektywniej ją wykorzystują.

Do roku 2009 systematycznie zmniejszała się liczba kuracjuszy pełnopłatnych. Od roku 2010 obserwuje się trendy wzrastające, co z pewnością jest wyrazem dużego zapotrzebowania Polaków na lecznictwo uzdrowiskowe. Obecnie czas oczekiwania na pobyt w sanatorium (w zależności od województwa trwa od 1 do 2 lat) oraz pewnego rodzaju reglamentacja tych usług przez NFZ (przysługuje jeden pobyt na 2 lata) powoduje, że Polacy częściej decydują się na kuracje pełnopłatne w uzdrowiskach łącząc wypoczynek z leczeniem i rehabilitacją. Duży popyt na usługi tego sektora ochrony zdrowia jest warunkowany zmianami demograficznymi 


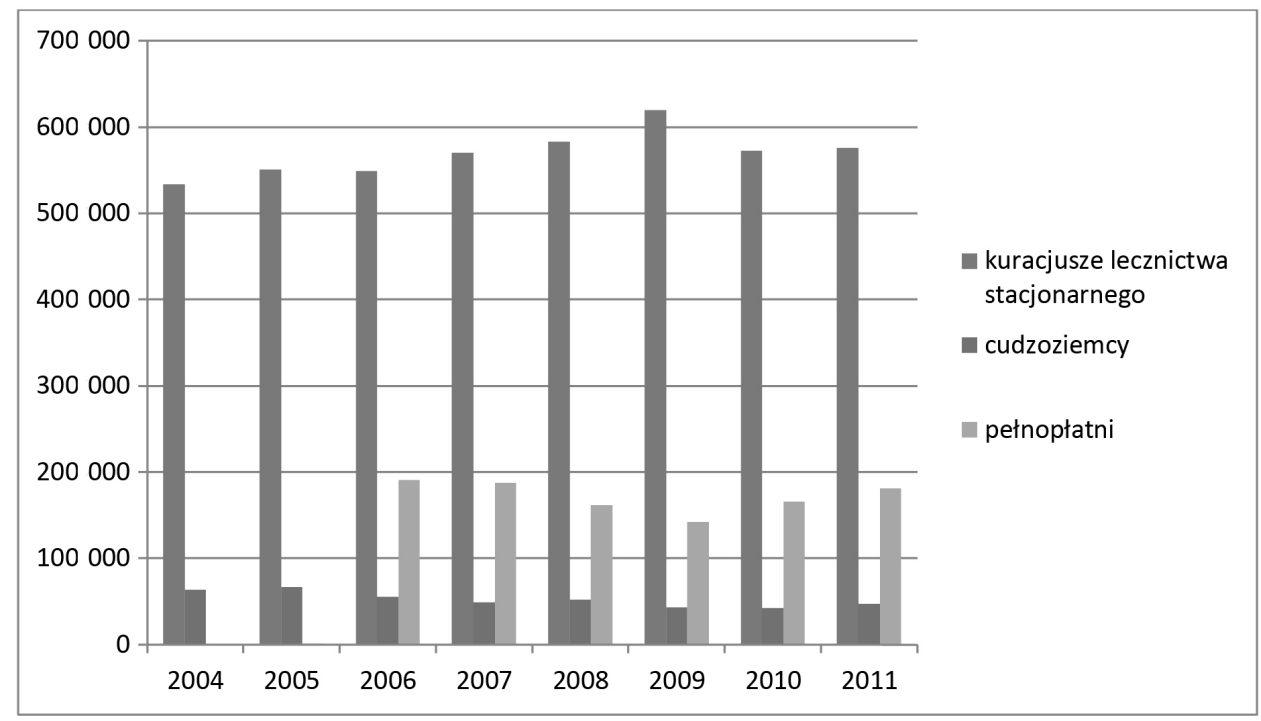

Rysunek 4. Liczba cudzoziemców i kuracjuszy pełnopłatnych w stosunku do liczby pacjentów lecznictwa stacjonarnego w latach 2004-2011

Źródło: jak do rys. 2; Zdrowie i ochrona zdrowia w 2011 roku, GUS, Warszawa 2012.

występującymi w populacji Polaków, zwiększonymi dochodami i poprawą stopy życiowej. Wzrasta również świadomość społeczeństwa odnośnie do znaczenia profilaktyki, a także znaczenia zachowania i potęgowania własnego zdrowia. Świadczenia uzdrowiskowe kierowane są w przeważającej części do ludzi w starszym wieku. Szacowania na nie zapotrzebowania w kolejnych latach można dokonać śledząc zmiany w sytuacji demograficznej Polaków, a przede wszystkim obserwując trendy w długości życia polskiej populacji.

\section{Satysfakcja komercyjnych kuracjuszy polskich uzdrowisk - wyniki badań własnych}

Badania komercyjnych kuracjuszy przeprowadzono w 2011 roku. Wykorzystano grupę kuracjuszy z 16 polskich sanatoriów wytypowanych do udziału w badaniu w sposób opisany poniżej. Wstępnie określono, jako pożądaną, wielkość próby na 1886 osób, stanowiącą 50\% uśrednionej liczby komercyjnych kuracjuszy przebywających $\mathrm{w}$ polskich sanatoriach $\mathrm{w}$ czasie dwutygodniowego turnusu $\mathrm{w}$ roku $2010^{8}$.

\footnotetext{
${ }^{8}$ Podstawowe dane z zakresu ochrony zdrowia w 2010 roku, GUS, Warszawa 2011.
} 
Identyfikacji uzdrowisk i sanatoriów, w których miały zostać przeprowadzone badania, dokonano metodą losowania dwustopniowego zespołowego, ze stratyfikacją na miejsce położenia (teren nadmorski, nizinny, podgórski i góry) i interwałem numeracji uzdrowisk co 2 (50\% polskich uzdrowisk). W pierwszym etapie $\mathrm{z}$ listy 44 uzdrowisk statutowych ${ }^{9}$ wylosowano 22 . W następnym kroku dokonano osobnego losowania sanatoriów funkcjonujących w obrębie wylosowanego uzdrowiska. Dzięki temu wyodrębniono 43 sanatoria. Do dyrektorów tak ustalonych sanatoriów wysłano listy (z załączonym wzorem ankiety) z prośbą o wyrażenie zgody na przeprowadzenie badań. Ostatecznie uzyskano zgodę na badania w 16 sanatoriach. Taka procedura doboru próby zapewniła anonimowość osób badanych. Ostatecznie uzyskano 510 poprawnie wypełnionych kwestionariuszy. Podkreślić należy, że było to badanie autorskie w tym segmencie usług ze względu na objęcie nim kuracjuszy biznesowych, a także skalę przeprowadzonych badań.

Narzędzie badawcze stanowił opracowany kwestionariusz ankiety, składający się z dwóch części, każda z nich poprzedzona była instrukcją wypełniania. Część pierwsza kwestionariusza zawierała metryczkę oraz pytania dotyczące przyczyn pobytu w sanatorium. Do opracowania drugiej części kwestionariusza wykorzystano oryginalny instrument badawczy metody SERVQUAL ${ }^{10}$, który został zmodyfikowany o specyficzne dla usług zdrowotnych elementy i zaadaptowany na potrzeby niniejszej rozprawy. Pytania zawarte w drugiej części kwestionariusza reprezentowały pięć podstawowych zbiorów stanowiących determinanty jakości postrzeganej przez klienta:

- materialność usług,

- solidność,

- zdolność reagowania,

- pewność,

- empatia.

Respondenci odnosili się do 25 twierdzeń zawartych w kwestionariuszu dotyczących oczekiwań i percepcji usługi uzdrowiskowej. Swoje odczucia wyrażali

${ }^{9}$ Stan na wrzesień $2011 \mathrm{r}$.

${ }^{10}$ Metodologia SERVQUAL po modyfikacji z uwzględnieniem warunków lokalnych i charakteru usług jest wykorzystywana m.in. w badaniu usług turystycznych, finansowych, bibliotecznych, bankowych, ubezpieczeniowych i in. E. Rudawska, R. Kiecko, SERVQUAL - metoda badania ustug i jej praktyczne zestawienie, „Marketing i Rynek” 2000 nr 5, s. 23-28; A. Rudawski, Jakość programu radiowego w budowaniu wizerunku rozgłośni, „Zeszyty Naukowe Uniwersytetu Szczecińskiego" 2005, nr 414, s. 598-600; M. Sidor, SERVQUAL w badaniach jakości ustug bibliotecznych (przegląd wybranej literatury), Wyższa Szkoła Biznesu w Nowym Sączu, http://www.oss. wroc.pl/biuletyn/ebib16/sidor.html [dostęp: 26.01.2010]. 
w 5-stopniowej skali, gdzie 1 oznaczał kategoryczny sprzeciw wobec przedstawionego stwierdzenia, 5 zaś oznaczało zdecydowaną zgodę. Zestaw wyróżników jakości został przygotowany z zastosowaniem 5 grup determinant jakości przedstawionych powyżej, a także uzupełniony o dodatkowe elementy skonstruowane na potrzeby niniejszej pracy. Część druga kwestionariusza została rozszerzona o pytania otwarte dotyczące hierarchii ważności komponentów usługi uzdrowiskowej.

Analizie poddano 510 kwestionariuszy (33 odrzucono ze względu na niekompletność odpowiedzi). Rodzaj zastosowanych pytań umożliwił zarówno ilościową, jak i jakościową analizę zgromadzonych danych.

\section{Charakterystyka badanej próby}

Zmienne charakteryzujące badaną próbę zostały zamieszczone w metryczce kwestionariusza ankiety. Na podstawie ich analizy stwierdzono, że:

- $58,4 \%$ przebadanej próby stanowiły osoby w przedziale wiekowym 45-64 lata, $37,6 \%$ tej próby była aktywna zawodowo.

- Wśród przebadanych kuracjuszy 68,6\% stanowiły kobiety, 64,9\% respondentów pozostawało w związkach małżeńskich.

- $83,3 \%$ ankietowanych legitymowało się średnim i wyższym wykształceniem, w większości $(52,2 \%)$ byli to mieszkańcy dużych miast.

\section{Wnioski z przeprowadzonych badań}

Porównanie średnich ocen dla poszczególnych właściwości idealnego oraz realnego sanatorium wskazuje, że oczekiwania nabywców usługi sanatoryjnej co do jej jakości były bardzo wysokie. W większości przypadków średnia ocen wynosiła powyżej 4,5. Szczególnie wysokie oczekiwania związane były z materialnymi atrybutami usługi, takimi jak zabiegi w miejscu zakwaterowania, czystość, możliwość korzystania z diet. Również wysoko oceniano właściwości charakteryzujące solidność i pewność usługi, a wśród nich jakość i liczbę zabiegów, stosunek personelu do kuracjuszy, poszanowanie intymności w trakcie zabiegów, czas oczekiwania na zabiegi. Średnia ocen poniżej 4 wystąpiła w przypadku dwóch właściwości, tj.: organizacji czasu wolnego i możliwości skorzystania z zabiegów typu SPA, podkreślić należy również, że swobodny dostęp do Internetu nie jest właściwością, która ma istotne znaczenie dla osób badanych. 
Konfrontacja oczekiwań kuracjuszy z rzeczywistością nasuwa myśl, że jeszcze nie wszystkie uzdrowiska, czy też poszczególne sanatoria, mają przygotowaną atrakcyjną, innowacyjną i konkurencyjną ofertę dla swoich klientów. Wyniki badań dowodzą, że usługi świadczone kuracjuszom w czasie pobytu w sanatoriach nie zawsze w pełni ich satysfakcjonują. Średnią ocen poniżej 4 uzyskały takie właściwości, jak możliwość skorzystania z zabiegów typu SPA $(3,10)$, dostęp do Internetu $(3,23)$, możliwość wykonywania badań lekarskich $(3,41)$, organizacja czasu wolnego $(3,30)$, informowanie o stanie zdrowia $(3,92)$, również cena turnusu nie była dla kuracjuszy zadowalająca $(3,75)$. Największe uznanie wśród kuracjuszy przebywających w sanatorium otrzymały takie właściwości, jak stosunek personelu do kuracjuszy, poszanowanie intymności w trakcie zabiegów, krótki czas oczekiwania na zabiegi i lokalizacja uzdrowiska.

Tabela 2. Porównanie właściwości idealnego i realnego sanatorium na podstawie opinii respondentów

\begin{tabular}{|c|l|c|c|c|c|c|}
\hline Lp. & Właściwości sanatorium & $\begin{array}{c}\text { Średnia } \\
\text { ocen dla } \\
\text { właści- } \\
\text { wości sa- } \\
\text { natorium } \\
\text { realnego }\end{array}$ & $\begin{array}{c}\text { Średnia } \\
\text { ocen dla } \\
\text { właści- } \\
\text { wości sa- } \\
\text { natorium } \\
\text { idealnego }\end{array}$ & $\begin{array}{c}\text { Różnica } \\
\text { między sa- } \\
\text { natorium } \\
\text { idealnym } \\
\text { a realnym }\end{array}$ & $\begin{array}{c}\text { Korelacje } \\
\text { dla prób } \\
\text { zależnych }\end{array}$ & $\begin{array}{c}\text { Test } \\
\text { T Studenta } \\
\text { - wartość }\end{array}$ \\
\hline 1 & Posiadanie basenu & 3,36 & 4,45 & 1,09 & 0,24 & 13,72 \\
\hline 2 & $\begin{array}{l}\text { Możliwość wykonywania } \\
\text { badań lekarskich }\end{array}$ & 3,41 & 4,39 & 0,98 & 0,33 & 13,55 \\
\hline 3 & Dostęp do Internetu & 3,23 & 4,03 & 0,80 & 0,18 & 8,92 \\
\hline 4 & Zabiegi typu SPA & 3,10 & 3,84 & 0,74 & 0,34 & 9,55 \\
\hline 5 & Organizacja czasu wolnego & 3,30 & 3,95 & 0,65 & 0,20 & 9,27 \\
\hline 6 & Cena turnusu & 3,75 & 4,37 & 0,62 & 0,40 & 11,34 \\
\hline 7 & $\begin{array}{l}\text { Zakwaterowanie i zabiegi } \\
\text { w tym samym budynku }\end{array}$ & 4,06 & 4,68 & 0,62 & 0,27 & 10,89 \\
\hline 8 & $\begin{array}{l}\text { Informowanie o stanie } \\
\text { zdrowia }\end{array}$ & 3,92 & 4,53 & 0,61 & 0,39 & 11,93 \\
\hline 9 & Warunki zakwaterowania & 4,01 & 4,61 & 0,60 & 0,29 & 13,52 \\
\hline 10 & $\begin{array}{l}\text { Czystość budynków i po- } \\
\text { mieszczeń }\end{array}$ & 4,14 & 4,68 & 0,54 & 0,18 & 10,93 \\
\hline 11 & $\begin{array}{l}\text { Wyposażenie w nowocze- } \\
\text { sny sprzęt rehabilitacyjny }\end{array}$ & 4,10 & 4,64 & 0,54 & 0,37 & 14,53 \\
\hline 12 & $\begin{array}{l}\text { Szybkie zaspokojenie } \\
\text { potrzeb }\end{array}$ & 4,12 & 4,61 & 0,49 & 0,39 & 11,17 \\
\hline
\end{tabular}




\begin{tabular}{|c|l|c|c|c|c|c|}
\hline 13 & $\begin{array}{l}\text { Personel rozumie po- } \\
\text { trzeby }\end{array}$ & 4,19 & 4,68 & 0,49 & 0,30 & 10,65 \\
\hline 14 & $\begin{array}{l}\text { Dostosowanie świadczeń } \\
\text { do kuracjuszy }\end{array}$ & 4,24 & 4,72 & 0,48 & 0,30 & 10,86 \\
\hline 15 & $\begin{array}{l}\text { Jakość zabiegów fizyko- } \\
\text { terapeutycznych }\end{array}$ & 4,30 & 4,76 & 0,46 & 0,33 & 10,66 \\
\hline 16 & $\begin{array}{l}\text { Czas oczekiwania na wi- } \\
\text { zytę lekarską }\end{array}$ & 4,13 & 4,59 & 0,46 & 0,27 & 9,13 \\
\hline 17 & Dostępność lekarza & 4,22 & 4,64 & 0,42 & 0,37 & 9,73 \\
\hline 18 & Indywidualne traktowanie & 4,31 & 4,66 & 0,35 & 0,41 & 9,40 \\
\hline 19 & Wyżywienie & 4,20 & 4,55 & 0,35 & 0,40 & 8,32 \\
\hline 20 & $\begin{array}{l}\text { Możliwość korzystania } \\
\text { z diet }\end{array}$ & 4,12 & 4,46 & 0,34 & 0,42 & 7,13 \\
\hline 21 & $\begin{array}{l}\text { Liczba zabiegów fizyko- } \\
\text { terapeutycznych }\end{array}$ & 4,42 & 4,73 & 0,31 & 0,43 & 8.07 \\
\hline 22 & Kompetencje personelu & 4,51 & 4,79 & 0,28 & 0,42 & 10,50 \\
\hline 23 & Dodatkowe zabiegi & 4,26 & 4,49 & 0,23 & 0,29 & 5,60 \\
\hline 24 & $\begin{array}{l}\text { Stosunek personelu do } \\
\text { kuracjuszy }\end{array}$ & 4,58 & 4,78 & 0,20 & 0,48 & 7,03 \\
\hline 25 & Poszanowanie intymności & 4,57 & 4,77 & 0,20 & 0,43 & 7,40 \\
\hline 26 & Oczekiwanie na zabiegi & 4,57 & 4,70 & 0,13 & 0,51 & 5,15 \\
\hline 27 & Lokalizacja & 4,41 & 4,53 & 0,12 & 0,42 & 3,81 \\
\hline
\end{tabular}

Uwaga: Poziom istotności dla testu T Studenta we wszystkich wypadkach wynosi: $p=0,000$, $N=510$.

Źródło: opracowanie własne na podstawie danych uzyskanych w wyniku badań empirycznych.

Rozdźwięk pomiędzy oczekiwaniami a doświadczeniami kuracjuszy najlepiej odzwierciedla istniejąca luka, wskazująca zarządzającym kierunki zmian oraz momenty, gdzie jakość usługi oferowanej kuracjuszowi odbiega od jakości przez niego oczekiwanej. Na rys. 5 przedstawiono luki doskonałości w odniesieniu do usługi sanatoryjnej świadczonej kuracjuszom biznesowym. Istniejące luki wskazują na obszary wymagające interwencji kadry zarządzającej, w celu poprawy jakości oferowanej usługi. Jednocześnie analiza luk pozwala na określenie stopnia zadowolenia czy wręcz satysfakcji kuracjuszy z otrzymanej oferty. 


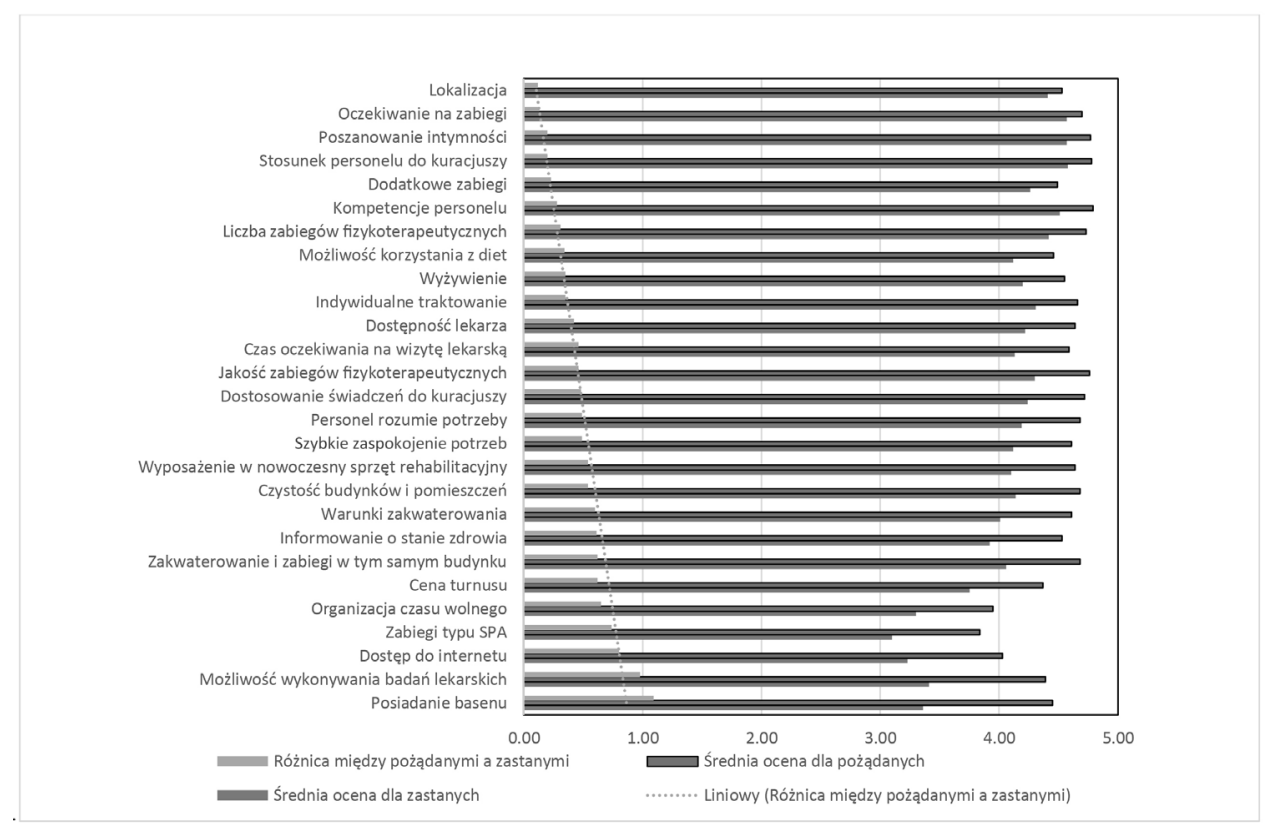

Rysunek 5. Różnice pomiędzy usługą idealną a otrzymaną

Źródło: opracowanie własne na podstawie analizy danych empirycznych.

Analiza danych przedstawionych na rys. 5 wskazuje luki doskonałości w odniesieniu do usługi sanatoryjnej świadczonej kuracjuszom biznesowym. Największa $(1,09)$ luka dotyczy infrastruktury i odnosi się do posiadania basenu przez uzdrowisko, czy też sanatorium, druga w kolejności (różnica 0,98 ) dotyczy możliwości wykonywania badań lekarskich, trzecia $(0,80)$ wskazuje na utrudnienia w dostępie do Internetu, w następnej kolejności są to zabiegi typu SPA, organizacja czasu wolnego i cena turnusu. Najmniejsze różnice (od 0,12 do 0,28$)$ dotyczyły lokalizacji uzdrowiska, czasu oczekiwania na zabiegi, poszanowania intymności w trakcie zabiegów, kompetencji personelu czy możliwości wykupienia dodatkowych zabiegów.

W pracy przyjęto założenie, że luki wyrażone w postaci różnicy średniej ocen poszczególnych właściwości sanatorium nie przekraczające wartości 0,35 świadczą o wysokim poziomie satysfakcji kuracjuszy. W przypadku przedstawianej usługi wartości te dotyczą następujących komponent usługi uzdrowiskowej:

- lokalizacji sanatorium,

- krótkiego czasu oczekiwania na zabiegi,

- poszanowania intymności i godności w czasie zabiegów,

- stosunku personelu do kuracjuszy, 
- możliwości wykupienia dodatkowych zabiegów,

- kompetencji i fachowości personelu,

- liczby zabiegów fizykoterapeutycznych,

- możliwości korzystania z diet,

- wyżywienia,

- indywidualnego traktowania kuracjusza.

O braku zadowolenia możemy mówić wówczas, gdy różnica pomiędzy właściwością oczekiwaną a otrzymaną przekracza wartość 0,65 . W badanej usłudze sanatoryjnej takie różnice zaobserwowano w przypadku następujących cech sanatorium:

- organizacja czasu wolnego kuracjuszy,

- możliwość skorzystania z zabiegów typu SPA,

- dostęp do Internetu,

- możliwość wykonywania badań diagnostycznych,

- posiadanie przez sanatorium basenu.

W przypadku pozostałych właściwości sanatorium różnice średniej ocen wahały się w przedziale $0,64-0,42$. W przypadku tych cech możemy mówić o zadowoleniu kuracjuszy.

Podsumowując wypada stwierdzić, że poziom zadowolenia kuracjuszy z otrzymanej oferty jest stosunkowo wysoki, brak satysfakcji występował jedynie w przypadku właściwości, które mogą występować ponadstandardowo w sanatorium i są dla kuracjusza pewnymi bonusami. Są to np. zabiegi SPA, dostęp do Internetu czy dobrze zorganizowana animacja.

Istniejące luki wskazują na obszary wymagające interwencji kadry zarządzającej w celu poprawy jakości oferowanej usługi. Jednocześnie analiza luk pozwala na określenie stopnia zadowolenia czy wręcz satysfakcji kuracjuszy z otrzymanej oferty.

\section{Zakończenie}

Zachowania polskich konsumentów w ostatnich dekadach podlegają dynamicznym zmianom. Jest to m.in. efekt oddziaływania procesów globalizacji, pojawiania się nowych trendów, rozwoju technik informatycznych. Prezentowana publikacja daje charakterystykę współczesnego kuracjusza na rynku usług 
uzdrowiskowych, określa jego zachowania i ich determinanty. Wyniki przeprowadzonych badań pozwoliły na wyłonienie wiązki właściwości uzdrowisk, którym przypisano największy wpływ na usatysfakcjonowanie konsumentów usług uzdrowiskowych i które mogą być czynnikami budującymi długotrwałe relacje z nimi. Jednocześnie wskazano na istotne dla jakości usługi uzdrowiskowej obszary, w których występują niedostatki mające wpływ na jej jakość.

Podkreślić należy, że przeprowadzone badania mają charakter utylitarny i mogą pomóc kadrze zarządzającej sanatoriami ukształtować ofertę usługową w taki sposób, aby najpełniej usatysfakcjonowała kuracjusza biznesowego.

\section{Bibliografia}

DzU z 2005 r., nr 167, poz. 1399

Lalonde M., A New Perspective on the Canadians, Working Document, Minister of National Health and Welfare, Ontario 1974

Narodowy Rachunek Zdrowia za 2011 r. Materiał na konferencję prasową w dniu 23.07.2013 roku, Departament Badań Społecznych i Warunków Życia, GUS, Warszawa

Podstawowe dane z zakresu ochrony zdrowia 2005-2011 roku, GUS, Warszawa 2012

Podstawowe dane z zakresu ochrony zdrowia w 2010 roku, GUS, Warszawa 2011

Szymura-Tyc M., Marketing we wspótczesnych procesach tworzenia wartości dla klienta i przedsiębiorstwa, Wyd. Akademii Ekonomicznej, Katowice 2006 